\title{
PAPER
}

\section{Inflammation and neuropathic attacks in hereditary brachial plexus neuropathy}

\author{
C J Klein, P J B Dyck, S M Friedenberg, T M Burns, A J Windebank, P J Dyck
}

J Neurol Neurosurg Psychiatry 2002;73:45-50

See end of article for authors' affiliations

...................

Correspondence to: Dr Christopher J Klein, Mayo Clinic, 200 First Street SW, Rochester, Minnesota 55905, USA;

klein.christopher@mayo.edu

Received

3 December 2001

In revised form

14 February 2002

Accepted 4 March 2002

\begin{abstract}
Objective: To study the role of mechanical, infectious, and inflammatory factors inducing neuropathic attacks in hereditary brachial plexus neuropathy (HBPN), an autosomal dominant disorder characterised by attacks of pain and weakness, atrophy, and sensory alterations of the shoulder girdle and upper limb muscles.

Methods: Four patients from separate kindreds with HBPN were evaluated. Upper extremity nerve biopsies were obtained during attacks from a person of each kindred. In situ hybridisation for common viruses in nerve tissue and genetic testing for a hereditary tendency to pressure palsies (HNPP; tomaculous neuropathy) were undertaken. Two patients treated with intravenous methyl prednisolone had serial clinical and electrophysiological examinations. One patient was followed prospectively through pregnancy and during the development of a stereotypic attack after elective caesarean delivery.

Results: Upper extremity nerve biopsies in two patients showed prominent perivascular inflammatory infiltrates with vessel wall disruption. Nerve in situ hybridisation for viruses was negative. There were no tomaculous nerve changes. In two patients intravenous methyl prednisolone ameliorated symptoms (largely pain), but with tapering of steroid dose, signs and symptoms worsened. Elective caesarean delivery did not prevent a typical postpartum attack.

Conclusions: Inflammation, probably immune, appears pathogenic for some if not all attacks of HBPN. Immune modulation may be useful in preventing or reducing the neuropathic attacks, although controlled trials are needed to establish efficacy, as correction of the mutant gene is still not possible. The genes involved in immune regulation may be candidates for causing HBPN disorders.
\end{abstract}

$\mathrm{H}$ ereditary brachial plexus neuropathy $(\mathrm{HBPN})$ is an autosomal dominant disorder with periodic attacks of unilateral or asymmetrical pain, weakness, atrophy, and sensory alterations of the shoulder girdle and upper limb muscles, usually attributed to involvement of proximal upper limb nerves or the brachial plexus. ${ }^{1}$ The symptoms, distribution of neurological findings, and course of the attacks are probably not distinguishable from immune brachial plexus neuropathy (Parsonage-Turner syndrome). Postpartum, posttraumatic, or post-shock occurrence of neuropathic attacks, minor dysmorphic features (hypotelorism, epicanthic folds, short stature), a tendency to recur, and a family history distinguish the familial from the non-familial variety. In the latter, inflammation of the brachial plexus has been found..$^{234}$ The chromosome localisation of the disorder in some families with HBPN has been assigned to $17 \mathrm{q} 25,{ }^{5}$ but genetic heterogeneity has also been reported. ${ }^{6}$

In this study, we addressed the question of whether attacks in HBPN are attributable to altered immunity-an idea previously proposed for postpartum attacks. 'In non-familial cases, no evidence has been found that events of labour or parturition induce attacks. ${ }^{7}$ We also explored whether labour and the mechanical shear forces exerted on the brachial plexus during parturition are implicated in postpartum HBPN attacks. Lastly, we investigated whether common viruses or a tomaculus neuropathy are implicated in attacks.

\section{METHODS}

\section{Clinical examination}

Patients 1 and 2 had serial quantitative evaluation of impairments and symptoms. Impairments were assessed by the Neuropathy Impairment Score (NIS) - a standard point summation of bilateral weakness, reflex, and sensation loss. Symptoms were assessed by the Neuropathy Symptoms and
Change (NSC) score-a standard summation of the number, severity, and change of motor, sensory, and autonomic symptoms. ${ }^{8}$ Patients without impairments or symptoms have NIS and NSC scores of 0 and 0 . With increasing impairment and symptoms the scores for both NIS and NSC increase.

\section{Electrophysiological and quantitative sensation testing} methods

The methods of nerve conduction and electromyography used were standard and have been described previously. ${ }^{9}$ Quantitative sensation testing was carried out for vibration, cooling, and heat pain threshold (HP 5, 0.5, and 5-0.5), using CASE IV (Rochester, Minnesota, USA). ${ }^{10}$

\section{Nerve biopsy}

Distal branches of the superficial radial nerve were biopsied in three patients during neuropathic attacks. One patient (patient 3), previously described, ${ }^{1}$ had a proximal median nerve fascicular biopsy taken under general anaesthesia. The procedures for fixation, histological processing, and evaluation of the nerve have been described.$^{11}$ In situ hybridisation of nerve paraffin sections was done in all four cases to identify cytomegalovirus, herpes simplex, varicella-zoster, and Epstein-Barr viruses. ${ }^{12} 13$

\section{RESULTS}

\section{Clinical features and response to treatment}

The four patients from whom nerve biopsies were obtained are unrelated (fig 1), and had no known viral illnesses before their

Abbreviations: HBPN, hereditary brachial plexus neuropathy; HMSN, hereditary motor and sensory neuropathy; HNPP, hereditary neuropathy with pressure palsies; NIS, Neuropathy Impairment Score; NSC,

Neuropathy Symptoms and Change score 
Table 1 Clinical features, course, and treatment in four cases of hereditary brachial plexus neuropathy

\begin{tabular}{|c|c|c|c|c|c|c|c|c|c|c|}
\hline Patient & $\begin{array}{l}\text { Age (y) at } \\
\text { lst } \\
\text { attack/ } \\
\text { sex }\end{array}$ & $\begin{array}{l}\text { Age (y) } \\
\text { at biopsy }\end{array}$ & $\begin{array}{l}\text { No of } \\
\text { episodes }\end{array}$ & $\begin{array}{l}\text { Clinical features of } \\
\text { current attack }\end{array}$ & CSF & $\begin{array}{l}\text { HNPP } \\
\text { gene } \\
\text { testing }\end{array}$ & $\begin{array}{l}\mathrm{CT} / \mathrm{MRI} \\
\text { plexus }\end{array}$ & $\begin{array}{l}\text { Family } \\
\text { members } \\
\text { affected }\end{array}$ & $\begin{array}{l}\text { STreatment of } \\
\text { biopsied attack }\end{array}$ & Treatment response \\
\hline 1 & $19 / \mathrm{F}$ & 28 & 3 & $\begin{array}{l}\text { Painful weakness } \\
\text { bilaterally; BPN postpartum }\end{array}$ & $\mathrm{N}$ & Neg & $\mathrm{Neg}$ & 17 & $\begin{array}{l}\text { IV MP tapered over } \\
1.5 \text { months }\end{array}$ & $\begin{array}{l}\text { Dramatic pain } \\
\text { reduction; worsened } \\
\text { pain and weakness } \\
\text { with steroid taper }\end{array}$ \\
\hline 2 & $10 / M$ & 46 & 4 & Painful weakness $L>R$; BPN & $\begin{array}{l}\text { Protein } \uparrow \\
(60 \\
\mathrm{mg} / \mathrm{dl})\end{array}$ & Neg & ND & 7 & $\begin{array}{l}1 \mathrm{~g} \text { IV MP } \times 3 \mathrm{~d} \text {; } \\
\text { then } 60 \mathrm{mg} \\
\text { prednisone } \times 1 \mathrm{~m} \text {; } \\
\text { then } 50 \mathrm{mg} \times 1 \mathrm{~m} \text {; } \\
\text { then tapered off }\end{array}$ & $\begin{array}{l}\text { Dramatic pain } \\
\text { reduction; worsened } \\
\text { pain and possible } \\
\text { weakness with steroid } \\
\text { taper }\end{array}$ \\
\hline 3 & $18 / \mathrm{F}$ & 21 & 2 & $\begin{array}{l}\text { Painful weakness } \\
\text { bilaterally; BPN postpartum }\end{array}$ & $\mathrm{N}$ & ND & ND & 11 & $\begin{array}{l}\text { Prednisone } 60 \\
\mathrm{mg} / \mathrm{d} \text { tapered over } \\
3 \text { weeks }\end{array}$ & Uncertain \\
\hline 4 & $9 M$ & 28 & 3 & Painful weakness R; BPN & $\mathrm{N}$ & Neg & Neg & 1 * & $\begin{array}{l}\text { Prednisone } 80 \\
\mathrm{mg} / \mathrm{d} \text { tapered over } \\
4 \text { weeks }\end{array}$ & Uncertain \\
\hline
\end{tabular}

*Patient's father's history, examination, and nerve conduction/EMG studies (performed by us) consistent with recurrent brachial plexopathy. BPN, brachial plexus neuropathy; CSF, cerebrospinal fluid; CT, computed tomography; d, day; HNPP, hereditary brachial plexus neuropathy; IV intravenous; L, left; $m$, month; MP, methyl prednisolone; MRI, magnetic resonance imaging; $N$, normal; $N D$, not done; $R$, right; $y$, year;

present neuropathic attacks. Patients 2 and 4 were unaware that they had a family history of the disorder until other family members were evaluated. Patients 1 and 3 had postpartum attacks and close-set eyes. The clinical findings are summarised in table 1 .

\section{Patient 1}

Patient 1 had previous attacks of brachial plexus neuropathy including postpartum attacks. Such postpartum attacks had occurred in 10 of 12 affected women in her family. Her first postpartum attack, six years earlier, resulted in painful left hand and arm paresis. In her most recent pregnancy we studied her prospectively at 16, 26, and 35 weeks of gestation and after parturition at 2, 3, 20, and 40 weeks. Throughout pregnancy her NIS and NSC scores were 0 and 0 (normal).

As it was not known whether avoidance of labour might prevent postpartum attacks (none of the patient's kindred with postpartum attacks had undergone caesarean delivery), mechanical forces of labour on the brachial plexus were avoided by elective caesarean section under epidural anaesthesia at 37 weeks. Throughout delivery she had no neuromuscular symptoms; however, three hours after delivery she awoke with severe left shoulder pain and dysaesthesia and paraesthesia of the thumb and forearm (features characteristic of her previous attacks).

Intravenous methyl prednisolone was initiated within six hours of symptom onset in a dose of $500 \mathrm{mg} /$ day for four days. She reported dramatic resolution of pain within hours of the start of treatment-quite unlike the continuous pain which followed her previous parturition. On the fifth day she was discharged from hospital without symptoms.

Three days after stopping intravenous methyl prednisolone, the pain returned in both arms and shoulders and she developed left thumb weakness. She was again given intravenous methyl prednisolone $500 \mathrm{mg}$ for two days with pain resolution. Five days after completing the second course of prednisolone, painful symptoms returned along with acute (within hours) right wrist weakness.

At two weeks postpartum her NIS score was 18 points, and one week later 36 points, with worsened symptoms on NSC testing. The changed subscore of the NSC (comparing symptoms at interview with those at discharge after initial intravenous methyl prednisolone) showed worsening $(-20$ points). Given her clinical decline, a superficial radial nerve biopsy was obtained to characterise the pathological alterations and to justify treatment choices. After reviewing the biopsy, intravenous methyl prednisolone $500 \mathrm{mg}$ per treatment was reinitiated twice a week for two weeks (four weeks postpartum). She again had improvement in pain and no new symptoms.

Twenty weeks after onset of the neuropathic attack she had hyperaesthesia of the hands and forearms. Her repeat NIS was unchanged at 36.5 points. At 40 weeks after attack onset her NIS score was 19 points and the NSC was normalised for symptoms of pain, with the sensory and motor deficit remaining as the primary abnormality. At the time of her previous postpartum attack, she had had difficulty in caring for her infant, typing, and opening doors at one year postpartum;

Table 2 Nerve biopsy results in hereditary brachial plexus neuropathy

\begin{tabular}{|c|c|c|c|c|c|c|c|}
\hline Patient & Nerve & Inflammation* & Distribution & $\begin{array}{l}\text { Axonal } \\
\text { degeneration }\end{array}$ & $\begin{array}{l}\text { In situ } \\
\text { hybridisationt }\end{array}$ & $\begin{array}{l}\text { Density of } \\
\text { myelinated fibres }\end{array}$ & Other \\
\hline 1 & Radial sensory & $\begin{array}{l}\text { Mononuclear } \\
\text { multiple infiltrates } \\
\text { (moderate) }\end{array}$ & $\begin{array}{l}\text { Epineurial (perivascular); } \\
\text { vessel wall involvement/ } \\
\text { destruction }\end{array}$ & $\begin{array}{l}\text { Marked } \\
(17 \%) ; \\
\text { multifocal }\end{array}$ & No hybridisation & Slightly reduced & $\begin{array}{l}\text { Rare early onion bulbs; } \\
\text { frequent regenerating } \\
\text { clusters; thin myelin }\end{array}$ \\
\hline 2 & Radial sensory & $\begin{array}{l}\text { Mononuclear } \\
\text { multiple infiltrates } \\
\text { (small) }\end{array}$ & $\begin{array}{l}\text { Epineurial; endoneurial; } \\
\text { subperineurial } \\
\text { (perivascular); vessel wall } \\
\text { involvement/ destruction }\end{array}$ & Severe $(95 \%)$ & No hybridisation & $\begin{array}{l}\text { Moderately } \\
\text { reduced }\end{array}$ & $\begin{array}{l}\text { Diffuse axonal } \\
\text { degeneration; } \\
\text { regenerating clusters; } \\
\text { thin myelin }\end{array}$ \\
\hline 3 & $\begin{array}{l}\text { Median motor } \\
\text { (single } \\
\text { fascicle) }\end{array}$ & None & Not applicable & None & No hybridisation & Normal & $\begin{array}{l}\text { Frequent intervascular } \\
\text { neutrophils, probably } \\
\text { preparatory }\end{array}$ \\
\hline 4 & Radial sensory & $\begin{array}{l}\text { Mononuclear } \\
\text { infiltrate (individual) }\end{array}$ & Epineurial; perivascular & None & No hybridisation & Normal & $\begin{array}{l}\text { Thin myelin; } \\
\text { regenerating clusters }\end{array}$ \\
\hline
\end{tabular}

*Collections of mononuclear inflammatory cells: individual, <10 cells; small, 10-49 cells; moderate, 50-99 cells; large, $\geqslant 100$ cells.

†For cytomegalovirus, Epstein-Barr virus, varicella-zoster virus, and herpes simplex virus. 

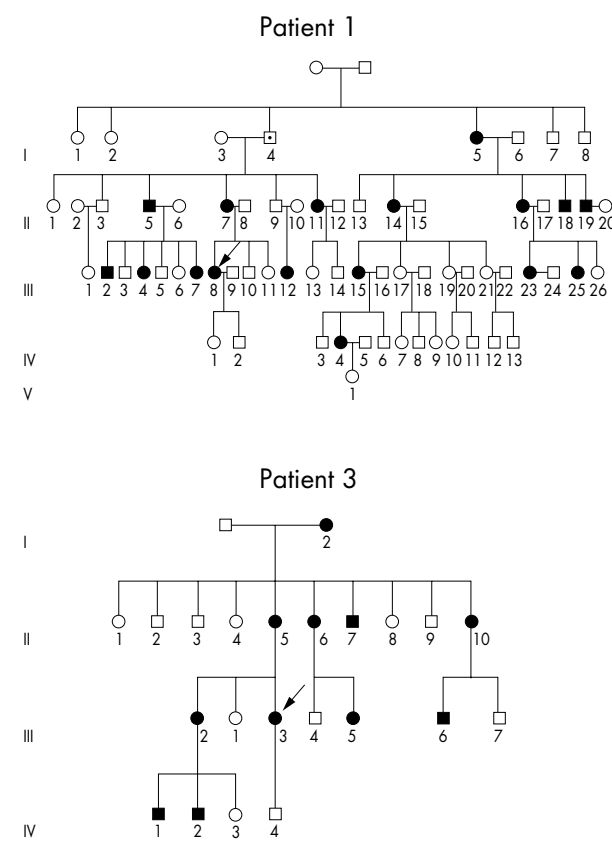

Patient 2

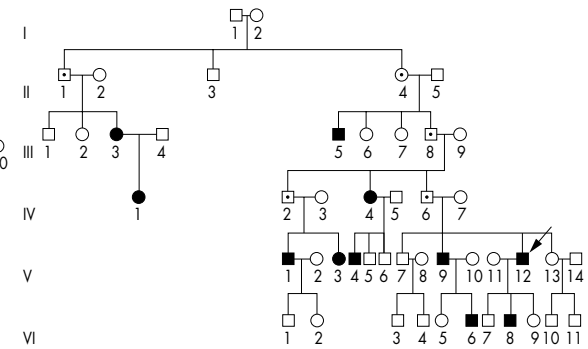

Patient 4

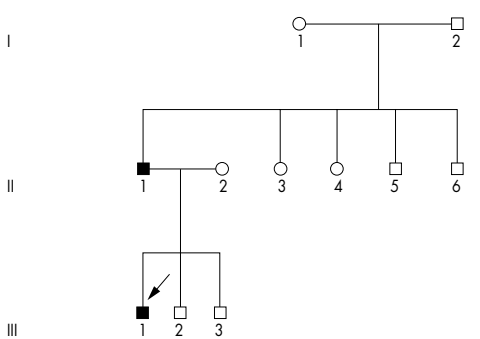

\section{Symbol definitions $\bigcirc \square$ Unaffected $\quad$ Affected $\odot \odot$ Possibly affected}

Figure 1 Pedigrees of the four affected individuals studied. The arrow identifies the proband and biopsied person. Patients 2 and 4 were initially not aware that other family members were also affected. Patient 4's father had previous attacks of arm paralysis related to rotator cuff injury and complicated carpal tunnel syndrome. His electromyogram showed bilateral chronic diffuse denervation of multiple muscles innervated by the brachial plexus and distal nerves.

these were all things she was able to do at 40 weeks from attack onset in her current attack.

\section{Patient 2}

Patient 2 had 11 known affected relatives. His history included four previous attacks, the first at 10 years of age and the last seven months before biopsy. This latter attack was characterised by painful left shoulder weakness in the trapezius and serratus anterior muscles. Two months before biopsy he developed subacute worsening pain in the left hand with sensory and motor loss in the arm and hand. New diffuse shoulder, arm, and hand weakness was found, with loss of sensation in the hand. A superficial radial nerve biopsy was obtained.

He was given intravenous methyl prednisolone (l g) on three successive days. He reported dramatic improvement in pain, so that he could sleep through the night for the first time in months, and developed no new symptoms. He was placed on tapering oral prednisone beginning at $60 \mathrm{mg} /$ day. His NIS was 27 points two weeks before treatment and remained unchanged two weeks later. His symptoms, as graded by the NSC scores, improved during treatment. The change in NSC subscore showed worsening before treatment ( -35 points) and two weeks after the prednisolone treatment there was improvement $(+13$ points $)$. The previous symptoms of jabbing, tingling, burning, and aching pain had abated. Four months later (on prednisone $10 \mathrm{mg} /$ day) his pain worsened (NSC change subscore +35 ) and he reported new weakness in hands and wrists, but the overall NIS score was essentially unchanged at 31 points.

Patients 3 and 4

Patients 3 and 4 had been treated with oral prednisone with uncertain benefit before being referred to us (table 1). Because of worsening symptoms of pain and sensory loss, nerve biopsies were obtained at two and three months, respectively, after attacks. Steroid treatment was not retried when the biopsies did not show inflammatory infiltrates.

\section{Electrophysiological and quantitative sensory studies Patient 1}

Patient 1 had serial nerve conduction studies, electromyography (EMG), and quantitative sensation testing before and after parturition. The nerve conduction and quantitative sensation results in the upper limbs were normal throughout pregnancy. Initial needle EMG (at 16 weeks of gestation) showed evidence of an old left brachial plexopathy (diffuse large motor unit potentials and no fibrillation potentials). At two weeks postpartum, quantitative sensation testing became abnormal, with increased vibration thresholds (hyposensitivity) in the hands. Nerve conductions and EMG were unchanged from the prepartum studies. Twenty weeks after the beginning of the attack, bilateral median and ulnar summated motor and sensory compound action potentials were reduced by $50 \%$ compared with earlier values. Cooling thresholds were raised (hyposensitivity) and heat pain thresholds decreased (hyperalgesia). At 40 weeks, median and ulnar motor and sensory responses improved and were normal in some cases; needle examination showed multifocal fibrillation potentials with neurogenic potentials. On quantitative sensation testing she remained hyposensitive to vibration but was no longer hyperalgesic on heat pain testing.

\section{Patient 2}

Patient 2 had limited nerve conductions with EMG nine weeks before and 12 weeks after initiation of intravenous methyl prednisolone. The nerve conduction studies were normal throughout and an EMG showed unchanging chronic neurogenic potentials with fibrillations in serratus anterior and trapezius muscles.

\section{Patients 3 and 4}

At the height of their attacks, patients 3 and 4 were also found to have nerve conduction and EMG abnormalities consistent with an active multifocal process in the brachial 


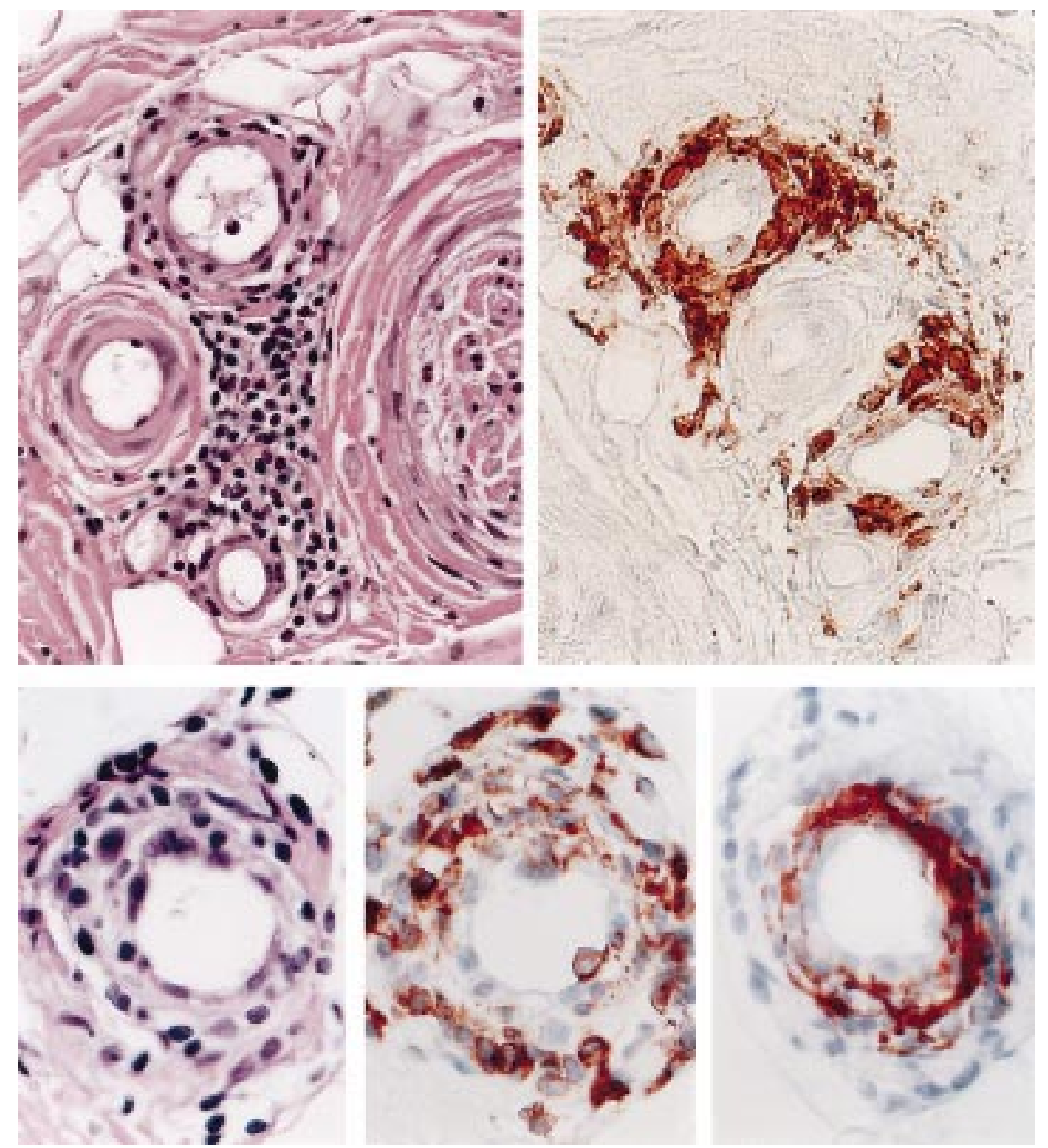

Figure 2 Top left: Transverse paraffin section of superficial radial nerve stained with haematoxylin and eosin from patient 1 with hereditary brachial plexus neuropathy (HBPN). There are prominent epineurial mononuclear cell infiltrates surrounding several small vessels adjacent to a nerve fascicle. The location, degree of inflammation, predominance of axonal degeneration in a multifocal pattern (table 2), and the pain relief from intravenous methyl prednisolone led us to conclude that the inflammation was pathogenic for the disorder. Top right: Transverse section of superficial radial nerve from patient 2 with HBPN also shows epineurial mononuclear cell infiltrates, here histochemically reacting to CD45, a lymphocyte marker. Some of the inflammatory cells appear to infiltrate vessel walls. The degree of inflammation shown was also seen in the endoneurium and subperineurium, indicating that inflammation, probably immune, was playing a pathogenic role in the fibre degeneration. Bottom: Serial sections of nerve microvasculature from patient 1 showing blood vessel involvement and tunica media disruption. Left lower: paraffin section, haematoxylin and eosin stain; middle lower: paraffin section reacted for CD45 (for leucocytes); right lower: paraffin section showing reaction to smooth muscle actin; note the disruption of the smooth muscle.

plexus or proximal upper limb nerves. Quantitative sensation testing was not done.

\section{Pathology findings}

The biopsy findings are summarised in table 2 and shown in figs 2 and 3 (patients 1 and 2). Biopsied nerves from both these patients showed multiple microvessels with epineurial perivascular inflammatory cell infiltrates and active axonal degeneration. The inflammation involved vessel walls and appeared disruptive. Fibrinoid necrosis was not seen. In patient 4 the neuropathic abnormalities were limited to small myelinated fibres with increased regenerating clusters and limited inflammation. Patient 3 was the only one not showing neuropathic or definite interstitial abnormalities, but the sample size of a single fascicle was small. In situ hybridisation of nerve at and away from sites of inflammation was negative for all viruses examined, while positive controls showed robust staining. Teased fibres did not show reduplicated myelin (tomaculi), and genetic testing for HNPP was negative in all three patients examined (table 1).

\section{DISCUSSION}

Some of the patients with HBPN studied here provide pathological evidence that inflammation, probably reflecting immune alterations, underlies at least some and perhaps all of their neuropathic attacks. The evidence for immune mechanism as the basis for attacks is as follows:

- there were prominent mononuclear cell infiltrates in nerve taken at the time of neuropathic attacks in two patientsone beginning three hours after parturition at a time when the immune status is changing to be less tolerant of foreign proteins;

- in situ hybridisation studies did not suggest viral infection;

- mechanical forces, as the basis for the neuropathy, were ruled out in one case by avoidance of labour and the act of parturition;

- intravenous methyl prednisolone appeared to ameliorate the symptoms.

There is limited information on the underlying pathological alterations in HBPN. Upper extremity nerve biopsies are not 


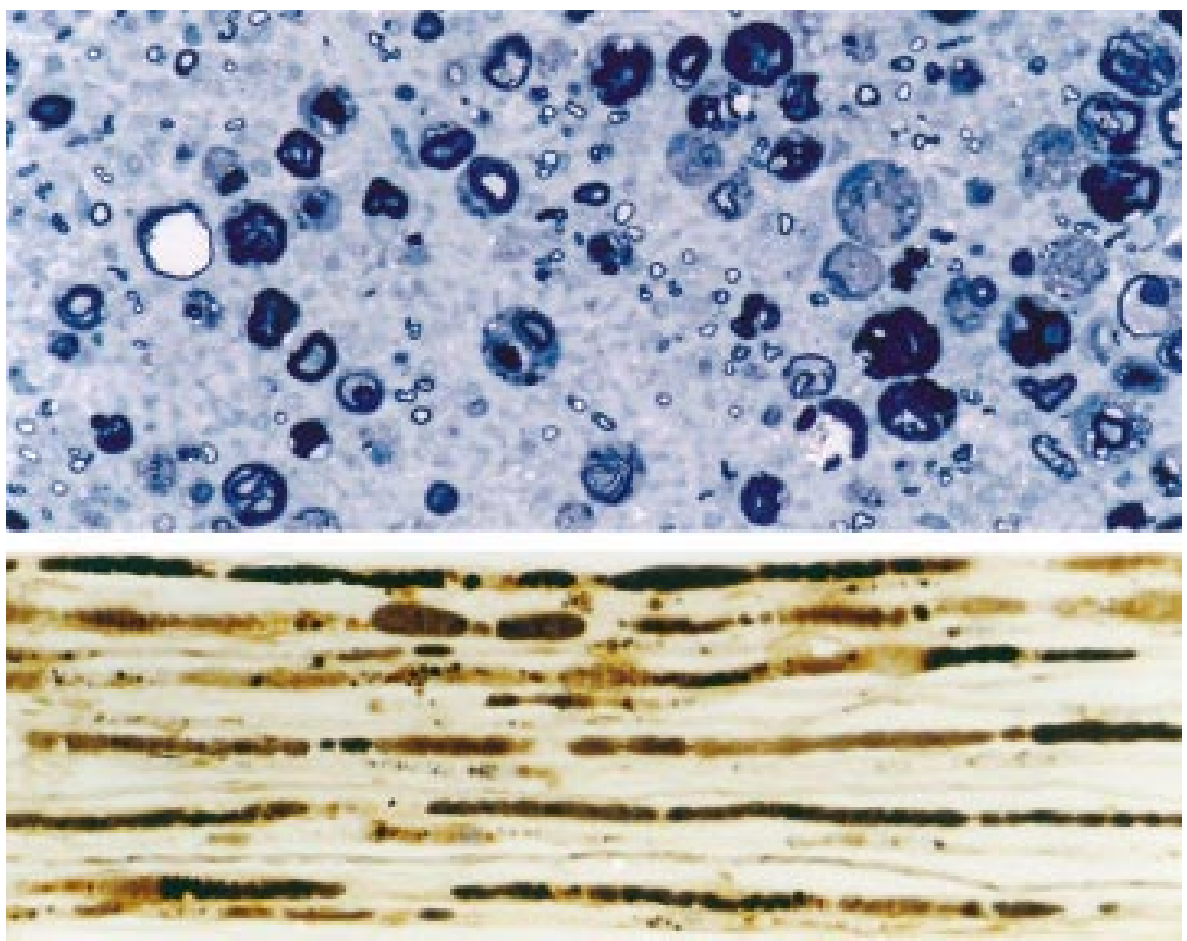

Figure 3 Top: Semithin transverse epoxy section of superficial radial nerve from patient 2 stained with methylene blue, showing severe axonal degeneration especially in large fibres, and empty nerve tubes with degenerating myelin. Bottom: Closely applied teased fibre preparations of the superficial radial nerve from patient 2 showing severe axonal degeneration at various stages.

reported. Bradley et al, studying recurrent brachial plexus neuropathy, found focal sausage shaped thickenings of reduplicated myelin (tomaculi) in sural nerve biopsies from two patients with lower extremity involvement and a family history. ${ }^{14}$ Our patients did not have tomaculi or deletion of $17 p 11.2$, the genetic alteration seen in HNPP (tomaculous neuropathy) (tables 1 and 2). The prominent perivascular epineurial inflammatory infiltrate observed in two of our four patients has also been described in non-inherited immune brachial plexus neuropathy. ${ }^{23}$ The severity and the epineurial, perivascular, and vascular wall localisation of the inflammation makes it unlikely that the inflammation is a reaction to fibre degeneration. Two of our patients with HBPN had prominent axonal degeneration, while those without inflammation had minimal or no neuropathic changes. The absence of neuropathic or interstitial changes in one of the patients may simply reflect the patchy nature of the illness, inadequate sampling, or a different cause-for example, genetic heterogeneity. ${ }^{6}$ Linkage analysis of our families will be important in identifying the specific chromosomal localisation of these pathological findings.

The fact that altered immunity may contribute to the pathogenesis of hereditary neuropathic injury was proposed earlier. ${ }^{15}{ }^{16}{ }^{17}$ In some patients with hereditary motor and sensory neuropathy (HMSN), worsening neuropathy has improved with immunotherapy. ${ }^{15}{ }^{16}$ In addition, Schmid et al have shown that immune factors play a role in the progression of an animal model of P0 mutated neuropathy. ${ }^{17}$ The results of our present study imply that immune mechanisms play a prominent role in the expression of HBPN, so genes involved in immune regulation may be the candidate genes.

Pathological studies of biopsied nerves from our four patients enabled us to draw several other important conclusions: first, the inflammatory infiltrates were usually associated with epineurial microvessels; second, axonal degeneration appears to be typical of the fibre alterations; and third, mononuclear cell infiltrates occurred in distal nerves, thus providing evidence of multifocal lesions extending to periph- eral nerves beyond the brachial plexus (a brachial plexus neuropathy). The pathological findings are consistent with the clinical response. Two of our patients appeared to respond to intravenous methyl prednisolone, at least as judged by improvement of symptoms (NSC), and acutely by stabilisation of signs (NIS). Pain relief appeared to be the greatest benefit of treatment. High dose intravenous methyl prednisolone seemed to be more beneficial then low dose prednisone.

The significance of the negative in situ nerve hybridisation studies for common viruses is unclear, but suggests that these viruses are unlikely to be the cause of the local inflammation. On the other hand occult or proximal plexus or nerve viral activation cannot be excluded as a trigger for an attack of immune inflammation, as has been suggested in Bell's palsy. ${ }^{18}$ Why distal upper extremity nerves and the brachial plexus are preferentially affected in this condition is unknown. Predominant upper or lower extremity involvement, however, has been observed in immune brachial plexus neuropathy ${ }^{234}$ and in diabetic and non-diabetic lumbosacral radiculoplexopathy. ${ }^{1921}$ In the latter illnesses, microvessel wall disruption has also been observed. Speculation about this anatomical selectivity might include impairment of the blood-nerve barrier at complex branching points within plexuses, or selective antigenic determinants within these regions. The former explanation seems less likely as the inflammation was also observed in distal nerves.

\section{Conclusions}

In at least some cases of HBPN, the mutant gene abnormality is expressed, resulting in an inflammatory response that is pathogenic for nerve attacks and axonal degeneration. This inflammation is multifocal (probably immune) in the brachial plexus and upper limb nerves. Intravenous methyl prednisolone appears to ameliorate the symptoms, especially the severe pain that characterises this disorder. In the sporadic form, oral and intramuscular steroids also provide relief from pain, but there is no evidence that early treatment alters the course of the disease. ${ }^{22}$ The results presented here suggest the 
need for formal clinical trials. Immune modulation may be useful in preventing or reducing the neuropathic expression of HBPN, though correction of the mutant gene abnormality is still not possible.

\section{ACKNOWLEDGEMENTS}

We gratefully acknowledge the help of Darlene Peterson and Mary Lou Hunziker in the preparation of the manuscript, and JaNean Engelstad for assistance in the preparation of the figures. We acknowledge the help of Ricardo V Lloyd MD for the in situ hybridisation studies, and Dr Christopher Lynch for proofing the manuscript. This work was supported in part from grants received from the National Institute of Neurologic Disorders and Stroke (NS36797).

\section{Authors' affiliations}

C J Klein, P J B Dyck, P J Dyck, Peripheral Neuropathy Research Center, Mayo Clinic, Rochester, Minnesota, USA

S M Friedenberg, Geisinger Medical Center, Department of Neurology, North Academy Avenue, Danville, Pennsylvania, USA

T M Burns, Department of Neurology, Lahey Clinic, Mall Road,

Burlington, Massachusetts, USA

A J Windebank, Department of Neurology, Mayo Clinic

\section{REFERENCES}

1 Windebank AJ. Inherited recurrent focal neuropathies. In: Dyck PJ, et al, eds. Peripheral neuropathy. Philadelphia: WB Saunders Co, 1984:1565-679

2 Cusimano MD, Bilbao JM, Cohen SM. Hypertrophic brachial plexus neuritis: a pathological study of two cases. Ann Neurol 1988;24:615-22.

3 Suarez GA, Giannini C, Bosch EP, et al. Immune brachial plexus neuropathy: suggestive evidence for an inflammatory immune pathogenesis. Neurology 1996;46:559-61.

4 Dyck PJB, Engelstad J, Suarez GA, et al. Biopsied upper limb nerves provide information about distribution and mechanism in immune brachial plexus neuropathy [abstract]. Neurology 2001;56:A395

5 Pellegrino JE, Rebbeck TR, Brown M, et al. Mapping of hereditary neuralgic amyotrophy (familial brachial plexus neuropathy) to distal chromosome 17q. Neurology 1996;46:1128-32.
6 Watts GD, O'Briant KC, Borreson TE, et al. Evidence for genetic heterogeneity in hereditary neuralgic amytrophy. Neurology $2001 ; 56: 675-8$

7 Lederman RJ, Wilbourn AJ. Postpartum neuralgic amyotrophy. Neurology 1996:47:1213-19.

8 Dyck PJ, Sherman WR, Hallcher LM, et al. Human diabetic endoneurial sorbital, fructose, and myo-inositol related to sural nerve morphometry. Ann Neurol 1980;8:590-6.

9 Kimura J. Electrodiagnosis in diseases of nerve and muscle: principles and practice. New York: Oxford University Press, 2001.

10 Dyck PJ, Zimmerman IR, Johnson DM, et al. A standard test of heat-pain responses using CASE IV. J Neurol Sci 1996;136:54-63.

11 Dyck PJ, Giannini C, Lais A. Pathologic alterations of nerves. In: Dyck PJ, et al, eds. Peripheral neuropathy. Philadelphia: WB Saunders, 1993:514-95.

12 Chang KL, Chen YY, Shibata D, et al. Description of an in situ hybridization methodology for detection of Epstein-Barr virus RNA in paraffin-embedded tissues, with a survey of normal and neoplastic tissues. Diagn Mol Pathol 1992;1:246-55.

13 Myers JL, Kurtin PJ, Katzenstein AL, et al. Lymphomatoid granulomatosis. Evidence of immunophenotypic diversity and relationship to Epstein-Barr virus infection. Am J Surg Pathol 1995;19:1300-12

14 Bradley WG, Madrid R, Thrush DC, et al. Recurrent brachial plexus neuropathy. Brain 1975;98:381-98.

15 Dyck PJ, Swanson CJ, Low PA, et al. Prednisone-responsive hereditary motor and sensory neuropathy. Mayo Clin Proc 1982;57:239-46.

16 Donaghy M, Sisodyia SM, Kennett R, et al. Steroid responsive polyneuropathy in a family with a novel myelin protein zero mutation. J Neurol Neurosurg Psychiatry 2000:69:799-805.

17 Schmid CD, Stienekemeier M, Oehen S, et al. Immune deficiency in mouse models for inherited peripheral neuropathies leads to improved myelin maintenance. J Neurosci 2000;20:729-35.

18 Murakami S, Mizobuchi M, Nakashiro Y, et al. Bell palsy and herpes simplex virus: identification of viral DNA in endoneurial fluid and muscle. Ann Intern Med 1996;124:27-30

19 Said G, Goulon-Goeau C, Lacroix C, et al. Nerve biopsy findings in different patterns of proximal diabetic neuropathy. Ann Neurol 1994:35:559-69.

20 Dyck PJB, Norell JE, Dyck PJ. Microvasculitis and ischemia in diabetic lumbosacral radiculoplexus neuropathy. Neurology 1999;53:2113-21.

21 Dyck PJB, Engelstad J, Norell J, et al. Microvasculitis in non-diabetic lumbosacral radiculoplexus neuropathy (LSRPN): similarity to the diabetic variety (DLSRPN). J Neuropathol Exp Neurol 2000;59:525-38.

22 Tsairis P, Dyck PJ, Mulder DW. Natural history of brachial plexus neuropathy: report on 99 patients. Arch Neurol 1972;27:109-17. 